\title{
LESS COMMON CELL TYPES IN THE TRACHEAL EPITHELIUM OF REPTILES
}

\author{
I. TĚŠík \\ Department of Histology and Embryology, 1st Medical Faculty, Charles University, 12800 \\ Prague
}

Received fanuary 11, 1991

\begin{abstract}
Těšík, I.: Less Common Cell Types in the Tracheal Epithelium of Reptiles. Acta vet. Brno, 61, 1992: 17-22.

Tracheal epithelium of representatives of 21 reptile species of 10 families was found to consist of several cell types. The first in the order of frequency were ciliated, goblet and granular cells followed by their considerably fewer precursors - basal cells, and rare intermediary cells. Plasma cells and Kultschitzky cells were found very rarely in the basal layers of the epithelium.

No evidence was obtained to indicate the presence of Clare cells and brush cells as have been described in mammals.
\end{abstract}

Tracheal epithelium, basal cell, intermediary cell, plasma cell, Kultschitzky cell

The morphology of the lung epithelium of reptiles has been the subject of numerous studies. The structure of their tracheal epithelium, on the other hand, has received little attention.

Light microscopic observations on the tracheal epithelium of the common lizard (Lacerta agilis) have been reported by Krause (1922). According to him it is made up of ciliated cells among which goblet-shaped elements can be found.

The ultrastructure of the tracheal epithelium in a number of other reptile species has been described by Těšík $(1978,1980,1981,1982,1984 a, b, 1986)$, Těšík and Nedvěd (1976) and Těšík and An talíková (1984). The most frequently occurring cell types in their studies were ciliated, granular and goblet cells. Their mutual numerical proportions vary with the order or family of the reptiles examined. The incidence of goblet and granular cells is governed by the law of reciprocity (Těšík 1978, 1982, 1986). In the tracheal epithelium of the Gekkonidae and the Lacertidae, e. g., secretory cells are represented only by granular elements (Těšík $1984_{i}$; Těšík and Nedvěd 1976). In the phylogenetic classification of reptiles typical mucinous cells in the trachea do not occur until in the Anguidae, along with still predominating granular cells. It is only in the Testudinata, Loricata, Ophidia and the Varanidae that goblet cells show a marked predominance in the tracheal epithelium. It can be said that their proportion increases with the decreasing proportion of granular cell. Ciliated cells occur only singly or in small clusters in the Gekkonidae. In the epithelium of the Lacertidae, Agamidae, Scincidae, Anguidae and the Testudinidae ciliated cells are more numerous, covering fairly large areas. On the other hand, the inner surface of the trachea in snakes, crocodiles and monitors is lined with an epithelium consisting substantially of ciliated cells, while the elements of secretory character, i.e. granular and goblet cells, are in the minority, occurring either singly or in more or less large clusters (T ěśík 1978, 1982).

Ciliated cells in reptiles show the basic morphological pattern as known in other vertebrate classes, although they may be markedly flattened. In consequence, the nucleus is then elongated and its long axis runs parallel to the basement membrane. The intercellular spaces between ciliated cells are larger than in birds and mammals, particularly in the basal parts of the epithelium. Also the interdigitations between adjacent cells are more numerous and more complex. The cilia of these cells are vigorous, growing from massively developed basal bodies. Striated rods below the blepharoplasts are long and show marked striation. Also the microvilli between the cilia are vigorous and branch fairly frequently. The cristae of the mitochondria of the subciliary zone of ciliated cells are often disposed irregularly and, more frequently than in birds and mammals, do not run perpendicularly to the long axis of the mitochondrion (Těšík 1980). 
In reptiles goblet cells (Fig. 3 and 4) may not necessarily show the true goblet-like shape but may be also cubic or slightly flattened in appearance. The structure of their lateral walls as well as the size and quantity of microvilli on their free surface depend apparently on the stage of their secretory cycle. The mucous granules filling the area below the nucleus arise by aggregation on minute mucin droplets. At first they are homogenous, but later a rather coarsely precipitated material can be seen on their surface layers. The granules gradually imbibe water, in consequence of which they differ in appearance within one and the same cell. By continued hydration the granules gain in volume, thus coming more and more in contact with one another, and push the cytoplasm towards the periphery, and the nucleus to the basal part of the cell ( $T$ ěśik 1981, 1984b).

Granular cells (Fig. 2) described by Těšík and Nedvěd (1976) in reptiles was the first evidence of the occurrence of granular cells in the upper respiratory tract of vertebrates. They have a large circular nucleus and bear numerous microvilli on their apical surface. The endoplasmic reticulum of the granular type and the Golgi apparatus are well developed. Minute granular mitochondria are scattered throughout the cytoplasm which also contains more or less numerous vacuoles and membrane-bounded granules of varying size and character. These formations are located mainly in the apical zone of the cell, but in contrast to the secretory granules of goblet cells, can be found also below the nucleus. The initial granule type from which the other granule types apparently develop is represented by circular electron-dense granules having a homogenous matrix. This then gradually condenses to form a markedly dense mass that generally produces lamellae which are often concentrically disposed. Eventually the lamellae colliquate and the granulum is changed into a vacuole the content of which empties on to the surface of the mucosa (Těsík 1981, 1984a; Těšík and Antalíková 1984).

\section{Materials and Methods}

Tracheal specimens were obtained from the middle of the trachea or just before the bifurcation of the bronchi from at least 3 representatives each of a total of 21 reptile species of 10 families (the Testudinidae, Crocodylidae, Gekkonidae, Agamidae, Scincindae, Lacertidae, Varanidae, Colubridae, Viperidae). All of them were adult except crocodiles which were between only 58 and $80 \mathrm{~cm}$ in length.

The tissue specimens were fixed on the one hand with $1 \% \mathrm{OsO}_{4}$ and on the other hand with $2.5 \%$ glutaraldehyde and postfixed with $1 \% \mathrm{OsO}_{4}$. They were embedded in Durcupan ACM and then sectioned with glass knives on a LKB ultramicrotome. Ultrathin sections we re counterstained according to Reynolds (1963) and examined with a Tesla BS 500 electron microscope.

\section{Results}

The tracheal epithelium of reptiles was found to consist, in addition to ciliated, granular and mucinous cells, of other cell types occurring there regularly though less frequently. They were basal, intermediary, plasma and Kultschitzky cells. (Their presence in the respiratory tract of the reptile species under study has not been described before.)

\section{Basal cells}

Basal cells were detected below ciliated, goblet and granular cells. Generally they were slightly flattened, but occasionally showed also the character of cubic elements. They were lying on a well perceptible lamina basalis. Closely adhering to it were also their thin projections showing marked pinocytotic activity. Attachment to adjacent cells was only through thin interdigitations and desmosomes. The nucleus was large and generally flattened, showing an irregular outline. The chromatin was concentrated in clusters located mainly below the nuclear membrane. The cytoplasm was relatively electron-lucent. It contained numerous minute vacuoles and, of cell organelles, only a small quantity of generally minute granular or more frequently elongated mitochondria. Occasionally it also showed fascicles of other filamentous structures, free ribosomes and, in some instances, suggestions of the developing endoplasmic reticulum and Golgi apparatus. The other organelles were either very slightly developed or entirely absent. 
As a whole, basal cells could be classified as considerably undifferentiated elements (see Plates XIX. to XXII., Fig. 7 to 10).

Intermediary Cells

The occurrence of intermediary cells was rare. They were found in only 3 reptile species: in Elaphe dione of the Colubridae (Fig. 4), Caiman crocodilus of the Crocodylidae (Fig. 6) and in Emys orbicularis of the Testudinidae (Fig. 5). They were located above a layer of basal cells and were generally elongated or spindle-shapes. Most of them extended as far as the luminal surface of the epithelium. Their apical plasma membrane showed thin and short microvillous projections. The cytoplasm which contained numerous minute vesicles, similarly to that of basal cells, varied in density. It showed scattered, mostly granular, mitochondria, free ribosomes, thin membranes of the endoplasmic reticulum and of the Golgi apparatus and, occassionally, clusters of glycogen granules (Fig. 5) or multiplied centrioles. These cells did not contain any secretory granules.

\section{Plasma Cells}

The occurrence of plasma cells in the epithelium was also rare. They, too, were found only in the basal layers of the epithelium. Where they extended as far as the tracheal lumen at those sites where the tracheal epithelial lining was low they were invariably overlaid with plasma projections of adjacent cells and never reached the epithelial surface itself (Fig. 14). The nucleus was large and, in general, located excentrically. The chromatin was generally clustered in conglomerates located both below the nuclear membrane and in the remaining karyoplasm. The most conspicuous finding in the cytoplasm was an abundantly developed granular endoplasmic reticulum with numerous cisternae (Fig. 11 to 16). Its presence can be regarded as evidence of a high proteosynthetic activity of these cell. Scattered among the membranes of this endoplasmic reticulum were granular mitochondria with distinct cristae. Also the Golgi apparatus was vigorously developed.

\section{Kultschitzky Cells}

Kultschitzky cells were found exclusively in the basal layers of the tracheal epithelium. They were scattered singly among adjacent cells and their occurrence was rare. Their nucleus was generally large. The cytoplasm was relatively electron-lucent and contained a weakly developed cytoplasmic reticulum and a small quantity of granular to filamentous mitochondria with distinct transverse cristae. The most conspicuous finding in the cytoplasm was the presence of a large number of minute, uniform membrane-bounded granules (Fig. 17 to 20). Upon higher magnification their contents appeared strongly osmiophilic and almost homogenous. However, an electron-lucent layer was seen immediately below the surface membrane.

Kultschitzky cells were not demonstrated in any of the snake species under study.

\section{Discussion}

As has been pointed out by Blenkinsopp (1967) basal cells arise by multiple division similarly to germinal cells of the epidermis. From our observations it appears that their gradual differentiation gives rise to further cells of the more 
superficial epithelial layers. In all reptile species they are similar, bearing the same characteristic traits of the species. However, it is impossible to distinguish into which definitive cell type these precursors will eventually develop. Apparently the change of the basal cell into the definitive type of the epithelial element occurs through an intermediate stage, represented by the intermediary cell. Presumably the whole process is completed very rapidly considering that the occurrence of intermediary cells in the epithelium is rare. In contrast to basal cells, these cells are considerably less uniform. Their cytoplasm varies in density, presumably depending on the fact whether their differentiation is directed towards the ciliary, goblet or granular cell type. Their cytoplasm contains no secretory granules. In reptiles, the goblet and granular cells arisen from intermediary cells retain the typical morphological traits that characterize them as specific separate species. (In birds and mammals it is possible to encounter cells bearing concurrently some traits of both granular and goblet elements.) As to the function of these cells, goblet cells are generally assumed to produce mucus. Granular cells, in our view, also contribute to the production of the surface mucosal film by their exocrine activity; it cannot be excluded, however, that their vigorous microvilli projecting from the free cellular surface enable them to modify even its viscosity by reabsorption of water. Ciliogenesis in intermediary cells has been observed by Jeffery and Reid (1975). In reptiles we found the same phenomenon accompanied in addition with accumulation of glycogen granules in the cytoplasm, obviously in those cells that were precursors of ciliated cells. In these cells multiplication of centrioles as bases of the future blepharoplasts of the cilia had preceded, in association with the differentiation process, and suggestions of the development of the subciliar mitochondrial zone were observed.

In the present study Kultschitzky cells in the respiratory epithelium of reptiles were rare. A similar observation in mammals has been made by Cutz et al. (1974), Moosavi et al. (1973), Jeffery and Reid (1973), Tarzakis et al. (1972) and Pearse (1977). More numerous Kultschitzky cells have been found only by Rosan and Lauweryns (1972) in human neonates and prematurely born infants. In lung-fish these cells have been studied by Scheuermann (1981). In our study only scattered Kultschitzky cells were found and then merely in the basal epithelial layers; they were never observed in clusters and did not produce bodies as described in mammals by Lauweryns et al. (1972). No evidence of Kultschitzky cells at all was obtained by us in any of the snake species examined. Direct contacts of Kultschitzky cells with intraepithelial nerve endings as described by Lauweryns et al. (1972) were not observed in the present study, but their existence can be assumed considering that the occurrence of both Kultschitzky cells and nerve endings is bound almost exclusively to the common basal layer of the epithelium and that it was in this layer that we found in several instances that nerve endings filled with synaptic vesicles were in direct contact with plasma membranes of the epithelial cells. Never did we observe a basal cell to change into a Kultschitzky cell and we do not assume that it might be its precursor. Neither did we observe the change of a ciliated cell into a goblet cell which has been described by Osada (1963) and has been admitted as possible by Fišer (1983).

Clare cells and brush cells which have been described as rare elements in the upper respiratory tract epithelium in mammals were not found by us in reptiles. 


\section{Málo běžné druhy buněk výstelkového epitelu prưdušnice plazů}

Vyšetřením vzorků epitelové výstelky průdušnice 21 druhů plazů náležejících 10 čeledím jsme zjistili, že tuto tvoři několik druhů buněk, jejichž frekvence výskytu je různá. Nejčastěji se $\mathrm{v}$ ní vyskytují buňky ciliární, pohárkové a granulární. Mnohem méně častá je $\mathrm{v}$ nich prítomnost jejich prekursorů - buněk bazálních. Ještě vzácněji lze zaznamenat výskyt buněk intermediálních. Velmi vzácně se pak v bazálních vrstvách epitelu vyskytuji buňky plazmatické a Kultšického.

$\mathrm{V}$ průdušnici plazů se nám nepodařilo prokázat prítomnost buněk Clarových a kartáčkových, které jsou popisovány u savců.

\section{Редкие клетки эпителия воздүхоносных трубок пресмыкающихся}

Ісследованием образцов эпителия тракеи 21 вида пресмыкающихся, принадлежащих к 10 семействам, нами было установлено, что он состоит из нескольких видов клеток, отличающихся разной частотой наличия. Чаще всего встречаются цилиарные, чащевидные и гранулярные клетки. Менее часто в них встречаются их клетки-предшественники базальные клетки. Еще реже можно встретить интермедиальные клетки. Очень редко в базальных слоях эпителия находятся плазматические клетки и клетки Культшицкого.

В трахее пресмыкающихся нам не удалось выявить наличие клеток Клара и щеточных клеток, описываемых у млекопитающихся.

\section{References}

BLENKINSOPP, W. K.: Proliferation of respiratory tract epithelium in the rat. Exp. Cell. Res., 46, 1967: 144-154

CUTZ, E.-CHAN, W.-WONG, V.-CONNEN, P. E.: Endocrine cells in rat fetal lungs: ultrastructural and histochemical study. Lab. Invest., 30, 1974: 458-464

FIŠER, F.: Treatment methods in the discharge of bronchial secretion. Institute for Further Training of Middle Health Personnel, Brno, 1983 (In Czech)

JEFFERY, P. K. REID, L.: New observations of rat airways epithelium: a quantitative and electron microscopic study. J. Anat., 120, 1975: 295-320

KRAUSE, R.: Mikroskopische Anatomie der Wirbeltiere. II. Vögel und Reptilien. Vereinigung wissenschaftlicher Verlag a Co., Berlin und Leipzig, 1922

LAUWERYNS, J. M.-PEUSKENS, J.: Neuroepithelial bodies (neuroreceptor or secretory organs?) in human infant bronchial and bronchiolar epithelium. Anat. Rec., 172, 1972: 471-481

MOOSAVI, H.-SMITH, P.-HEATH, D.: The feyerter cell in hypoxia. Thorax, 28, 1973: $729-741$

OSADA, M.: Electron microscopical observations on the human tracheal epithelium with special references to the ciliated cells. Arch. Histol. Jap., 24, 1963: 91-111

PEARSE, A. G. E.: The diffuse neuroendocrine system and the APUD concept. Med. Biol., 55, 1977: 115-125

REYNOLDS, E. S.: The use of lead citrate at high $\mathrm{pH}$ as an electron opaque stain in electron microscopy. J. Cell. Biol., 17, 1963: 208-212

ROSAN, R. C.-LAUWERYNS, J. M.: Mucosal cells of the small bronchioles of prematurely born human infants. Beitr. Path., 147, 1972: 145-174

SCHEUERMANN, D. W.: Histochemistry and fine structure of endocrine cells in the lung of Polypterus. Acta Anat. Abstr. VIth Europ. Anat. Congr. Hamburg, September 28, 1981: 133

TERZAKIS, J. A. - SOMMERS, S. C. - ANDERSSON, B.: Neurosecretory appearing cells of human segmental bronchi. Lab. Invest., 26, 1972: 127-132

TĚSfK, I.: Comparative morphological study on the tracheal epithelium of reptiles. Proc. XIXth Morphol. Congr. Praha, 1978: 457-462 
TĚSfK, I.: Ultrastructural morphology of the tracheal epithelium of some species of testudinates. Folia Morphol. (Prague), 4, 1982: 412-414

TẺSfK, I.: The ultrastructure of the tracheal epithelium in european common lizard (Lacerta agilis L.) and in sand lizard (Lacerta vivipara Jacq.). An t. Anz. Jena, 155, 1984a: 329-340

TẺ fK, I.: Morphological study of the functional cycle of the secretory cells of the upper respiratory tract epithelium of amphibians and reptiles. Folia Morphol. (Prague), 4, 1984b: 381-394

TĚSfK, I.: Comparsion of the morphology of upper respiratory tract epithelium in certain herpetofauna and avifauna representatives. Plzeň. lék. sborn. Suppl. 51, 1986: 117-121

TÉSfK, I. - ANTALfKOVA, L.: Histochemical study of the secretory granules in the granular cells of the tracheal epithelium in some species of lizards. Folia Morphol. (Prague), 1, 1984: $55-58$.

TÉSfK, I.-NEDVED, J.: Ultrastructure of the epithelium of trachea and extrapulmonary bronchi in Gekko gecko . Folia Morphol. (Prague), 24, 1976: 35-40 